\title{
Effects of Herbicides on Root Rot and Damping-off Caused by Rhizoctonia solani in Glyphosate-Tolerant Soybean
}

\author{
R. Harikrishnan and X. B. Yang, Department of Plant Pathology, Iowa State University, Ames 50011
}

\begin{abstract}
Harikrishnan, R., and Yang, X. B. 2002. Effects of herbicides on root rot and damping-off caused by Rhizoctonia solani in glyphosate-tolerant soybean. Plant Dis. 86:1369-1373.

Diseases caused by Rhizoctonia solani are one of many production constraints in soybeangrowing regions. Little information is available about the diseases in soybeans tolerant to different herbicides. In 1998 and 1999, studies were conducted to evaluate the plausible interaction between glyphosate-tolerant soybean and herbicides (glyphosate, imazethapyr, lactofen, and pendimethalin) on damping-off and root rot caused by $R$. solani under greenhouse and field conditions. The herbicides were applied at the product recommended field rate on glyphosatetolerant (Pioneer 93B01 and Pioneer 9344) and glyphosate-sensitive (BSR 101) soybean grown in soils infested with $R$. solani (isolate AG-4). Root rot and plant stand was significantly affected by soybean cultivars and herbicide treatments in the greenhouse study. A significant cultivar-treatment interaction was detected in the greenhouse study. The interaction implies that the cultivars responded differently to the various herbicides and especially to the herbicide pendimethalin. Plant stands of both cultivars were reduced by $R$. solani alone or in combination with different herbicides compared with the noninoculated control, and this was presumed to be due to damping-off. In a 2-year field study, cultivar and treatment main effects differed with respect to plant stand between years. In 1998, analysis of variance revealed a significant treatment effect on root rot severity but not plant stand. In 1999, analysis of variance revealed a significant effect of treatment on root rot severity and plant stand whereas cultivar showed a significant effect on plant stand only. In 1999, plant stands of both cultivars were similarly affected by most treatments. However, in BSR 101, the R. solani + pendimethalin + imazethapyr treatment significantly reduced plant stand compared with the $R$. solani + pendimethalin treatment. Root rot severity was generally low in both years of the field study. Some differential disease responses were detected between glyphosate-tolerant and glyphosate-sensitive cultivars following the application of certain herbicides in greenhouse and field studies. However, glyphosate-tolerant and glyphosate-sensitive cultivars reacted similarly to most herbicide treatments with respect to root rot and damping off.
\end{abstract}

The introduction of herbicide-tolerant crops is a significant advance in crop protection. Glyphosate-tolerant soybean (Glycine max), first introduced in 1996, was the first transgenic herbicide-tolerant crop. Since then, the acreage of glyphosatetolerant soybean has increased dramatically. As of 1998, transgenic soybean acreage accounted for nearly $38 \%$ of the total soybean acreage in the United States, of

Corresponding author: X. B. Yang

E-mail: xbyang@iastate.edu

Current address of R. Harikrishnan: Southwest Purdue Agricultural Program, 4369 N. Purdue Road, Vincennes, IN 47591.

This study was partially funded by the State of Iowa Fund and by Illinois and Iowa Soybean Research Councils. Part of a dissertation by $\mathrm{R}$. Harikrishnan for the Graduate College, Iowa State University. Journal Paper No. J 19648 of Iowa Agriculture and Home Economics Experiment Station, Ames, IA.

Accepted for publication 7 August 2002.

Publication no. D-2002-1022-01R

(C) 2002 The American Phytopathological Society which glyphosate-tolerant soybean cultivars constituted nearly $70 \%$ of the acreage (7). A gene isolated from a soil bacterium (14) mediates tolerance to glyphosate in the cultivars. The expected benefits of glyphosate-tolerant soybean cultivars are through decreases in herbicide usage, reduced plant injury, and better weed control.

Despite their many advantages, several scientific and social questions have been raised with the increased adoption of herbicide-tolerant crops (5). From the weed management point of view, the increasing acreage of glyphosate-tolerant cultivars could lead to a monoherbicide culture which, in turn, could lead to the development of herbicide-resistant weeds from increased selection pressure (15). Studies have shown that certain herbicides can lead to an increase in root diseases in various crops (1-3). For example, application of glyphosate has been shown to support increased populations of several fungi in soil $(10,18)$. Glyphosate was shown to block the production of phenolic compounds involved in disease resistance of host plants (9), thus leading to increased disease susceptibility in various crops $(8,11,19)$. An earlier study by Sanogo et al. (16) re- ported that both glyphosate-tolerant and glyphosate-sensitive soybean cultivars responded similarly to infection by Fusarium solani f. sp. glycines following herbicide application.

Rhizoctonia solani (teleomorph $=$ Than atephorus cucumeris) is a major pathogen of soybeans in the north-central United States (4). The fungus causes preemergence and post-emergence dampingoff, root rot, and aerial leaf blights on soybean around the world. Stand and yield losses up to $50 \%$ in soybean have been reported (17). However, knowledge about the effects of herbicides on the interaction of diseases caused by $R$. solani and herbicide-tolerant soybean cultivars is lacking. The objective of this research was to study the effects of four herbicides (pendimethalin [Prowl 3.3 EC], imazethapyr [Pursuit 2 AS], glyphosate [Roundup Ultra], and lactofen [Cobra 2 EC]) commonly used in soybean on the development of damping-off and root rot caused by $R$. solani in glyphosate-tolerant and glyphosate-sensitive soybeans.

\section{MATERIALS AND METHODS}

Greenhouse studies. Greenhouse experiments were conducted in 1998 and 1999. Autoclaved (at $140 \mathrm{kPa}$ for $1 \mathrm{~h}$ at $121^{\circ} \mathrm{C}$ ) and nonautoclaved mixtures of sand:soil $(1: 1, \mathrm{vol} / \mathrm{vol})$ were used for the experiments. The two soil conditions were used for comparison to see whether there is any differential response to $R$. solani and herbicides in the presence or absence of natural microflora. Pots $(15 \mathrm{~cm}$ in diameter) were filled with $1.8 \mathrm{~kg}$ of the sand:soil mixtures. Inoculum of $R$. solani (isolate AG-4) was produced on autoclaved oat kernels. One-liter jars filled with oat kernels, soaked in water overnight and drained, were autoclaved at $140 \mathrm{kPa}$ for 30 min at $121^{\circ} \mathrm{C}$. Following cooling, the jars were seeded with four to five 5-mm mycelial plugs from 2- to 3-day-old $R$. solani cultures on potato dextrose agar and incubated at $25 \pm 2{ }^{\circ} \mathrm{C}$ in dark for 3 weeks. Two soybean cultivars, glyphosate-tolerant Pioneer 93B01 (P 93B01) and glyphosatesensitive BSR 101, were planted at five seeds/pot. The pots were infested at either 0.5 or $1.0 \% \mathrm{wt} / \mathrm{wt}$ density with the $R$. solani inoculum. Three herbicides (pendimethalin, pre-emergence [Prowl 3.3 EC]; imazethapyr, post-emergence [Pursuit 2 AS]; and glyphosate, post-emergence [Roundup Ultra]) were applied at the product recommended rates; $1 \times$ recommended 
field rates were 1.7, 0.071, and $0.84 \mathrm{~kg}$ a.i./ha for pendimethalin, imazethapyr, and glyphosate, respectively. The required amount of each herbicide was calculated based on the surface area of the pot. Pendimethalin was applied after planting, whereas imazethapyr and glyphosate were applied at growth stage (GS) V2 and V4 (6). The different combinations of herbicides and inoculum densities of $R$. solani (treatments) applied are listed in Table 1. Treatments involving glyphosate were not applied to the glyphosate-sensitive soybean cultivar BSR 101 but were included in the data analysis as missing values. The treatments were completely randomized with four replications and the experiment was conducted twice. The experiments were terminated at GS R1 (6). Plant stand was determined by counting the number of plants at the end of the experiments. The differences in plant stands among various treatments were assumed to be due to damping-off. Root rot disease was assessed by visually scoring for root rot symptoms (after thoroughly washing the roots with

Table 1. Herbicides and inoculum densities of Rhizoctonia solani applied to a glyphosate-tolerant (Pioneer 93B01) and a glyphosate-sensitive (BSR 101) soybean cultivar in the greenhouse

\begin{tabular}{ll}
\hline Treatments $^{\mathbf{y}}$ & Inoculum density \\
\hline Control (no herbicide) & No inoculum \\
$\ldots$ & $R$. solani $0.5 \%$ \\
$\ldots$ & R. solani $1.0 \%$ \\
Pendimethalin, pre-emergence (Prowl 3.3 EC) & + R. solani $0.5 \%$ \\
Pendimethalin & + R. solani $1.0 \%$ \\
Imazethapyr, post-emergence (Pursuit 2 AS) GS V2 & + R. solani $0.5 \%$ \\
Imazethapyr GS V4 & + R. solani $0.5 \%$ \\
Imazethapyr GS V2 & + R. solani $1.0 \%$ \\
Imazethapyr GS V4 & + R. solani $1.0 \%$ \\
Glyphosate, post-emergence (Roundup Ultra) GS V2 & + R. solani $0.5 \%$ \\
Glyphosate GSV4 & + R. solani $0.5 \%$ \\
Glyphosate GSV2 $^{z}$ & $+R$. solani $1.0 \%$ \\
Glyphosate GSV4 $^{z}$ & $+R$. solani $1.0 \%$ \\
\hline
\end{tabular}

y GS denotes growth stages as described by Fehr et al. (6).

${ }^{\mathrm{z}}$ Glyphosate was not applied on glyphosate-sensitive cultivar BSR 101.

Table 2. Herbicide treatments applied to a glyphosate-tolerant (Pioneer 9344) and a glyphosatesensitive (BSR 101) soybean cultivar inoculated with or without Rhizoctonia solani under field conditions in 1998 and 1999

\begin{tabular}{|c|c|}
\hline Treatments & Inoculated \\
\hline Control (no herbicide) & No inoculum ${ }^{\mathrm{z}}$ \\
\hline No herbicide & + nonviable $R$. solani $(\mathrm{KI})$ \\
\hline$\ldots$ & R. solani ${ }^{\mathrm{Z}}$ \\
\hline Pendimethalin, pre-emergence (Prowl 3.3 EC) & $\ldots$ \\
\hline Imazethapyr, post-emergence (Pursuit 2 AS) & $\ldots$ \\
\hline Glyphosate, post-emergence (Roundup Ultra) & $\ldots$ \\
\hline Lactofen, post-emergence (Cobra 2 EC) & $\ldots$ \\
\hline Pendimethalin & $+R$. solani $\mathrm{i}^{\mathrm{z}}$ \\
\hline Imazethapyr & $+R \cdot$ solani $^{\mathrm{z}}$ \\
\hline Glyphosate & $+R \cdot$ solani $^{\mathrm{z}}$ \\
\hline Lactofen & $+R$. solani \\
\hline Pendimethalin + imazethapyr & $\ldots$ \\
\hline Pendimethalin + glyphosate & $\ldots$ \\
\hline Pendimethalin + lactofen & $\ldots$ \\
\hline Pendimethalin + imazethapyr & $+R$. solani $\mathrm{z}^{\mathrm{z}}$ \\
\hline Pendimethalin + glyphosate & $+R \cdot$ solani $^{\mathrm{z}}$ \\
\hline Pendimethalin + lactofen & $+R$. solani \\
\hline
\end{tabular}

${ }_{\mathrm{z}}^{\mathrm{z}}$ Treatments applied in 1998. Glyphosate treatments were not applied to glyphosate-sensitive BSR 101.

Table 3. Analysis of variance showing the effects of cultivar, soil, treatments, and their interactions on root rot severity caused by Rhizoctonia solani and plant stand under greenhouse conditions

\begin{tabular}{lcccccc}
\hline & & \multicolumn{2}{c}{ Root rot severity } & & \multicolumn{2}{c}{ Plant stand } \\
\cline { 6 - 7 } Source of variation $^{\mathbf{z}}$ & $\mathbf{d f}$ & $\boldsymbol{F}$ & $\boldsymbol{P}>\boldsymbol{F}$ & & $\boldsymbol{F}$ & $\boldsymbol{P} \boldsymbol{F}$ \\
\hline Cultivar (C) & 1 & 122.9 & 0.0001 & & 8.2 & 0.004 \\
Soil (S) & 1 & 0.10 & 0.75 & & 2.4 & 0.12 \\
C-S & 1 & 7.3 & 0.008 & & 0.1 & 0.75 \\
Treatment (T) & 6 & 9.2 & 0.0001 & & 24.7 & 0.0001 \\
C-T & 6 & 18.3 & 0.0001 & & 7.1 & 0.0001 \\
S-T & 6 & 2.1 & 0.05 & & 0.9 & 0.48 \\
C-S-T & 6 & 1.3 & 0.28 & & 1.3 & 0.28 \\
\hline
\end{tabular}

${ }^{\mathrm{z}}$ Data are from seven treatments, four replications, and two experiments.

running tap water) based on a 1-to-5 scale according to Nelson et al. (13).

Field studies. Studies were conducted in 1998 and 1999 at Iowa State University Hinds Farm, Ames, in a sandy loam (clay 17.8, sand 53.0, and silt $29.2 \%$ ) soil. A commercially grown glyphosate-tolerant cultivar, Pioneer 9344 (P 9344), was compared with BSR 101 (glyphosate-sensitive cultivar) in these studies. The cultivars were planted on 21 June and 10 May, respectively, for 1998 and 1999. Plots had four rows spaced $1 \mathrm{~m}$ apart and were $3 \mathrm{~m}$ in length. The rows were planted at the rate of approximately $50 \mathrm{seed} / \mathrm{m}$. Treatments (herbicides applied alone or in combination with or without $R$. solani) applied in 1998 and 1999 growing seasons are listed in Table 2. Treatments involving glyphosate were not applied to the glyphosatesensitive soybean cultivar BSR 101 but were included in data analysis as missing values. Treatments were arranged in a randomized complete block design with three replications.

Inoculum of $R$. solani (isolate AG-4) was produced as described earlier. Right before planting soybeans, 0.5 liter of infested oat kernels was spread uniformly by hand in an approximately 7- to 8-cm-deep furrow for the center two rows of all plots. Herbicide treatments were applied at the product recommended field rates as previously described using a $\mathrm{CO}_{2}$-pressurized handheld sprayer (R\&D Sprayers, Inc., Opelousas, Louisiana) with a volume of 150 liter $\mathrm{ha}^{-1}$ and at a pressure of approximately $210 \mathrm{kPa}$. Pre-emergence herbicide treatment (pendimethalin) application was made the day after planting, and postemergence herbicide treatment (imazethapyr, glyphosate, and lactofen) applications were made at V4 and V5 growth stages in 1998 and 1999, respectively. Plots that were not treated with herbicides were maintained weed free by hoeing when needed. Observations on plant stand (number of plants per meter) were taken at GS $\mathrm{R} 1$ on the center two rows of all plots to determine incidence of damping-off. After counting plants, the first five plants in the second row were dug to evaluate for root rot severity. Roots were thoroughly washed with running tap water to free soil and were rated for root rot severity as described earlier.

Data analysis. Analysis of the greenhouse data indicated no significant differences among the two-inoculum densities tested for all the variables measured; therefore, the data were combined for the twoinoculum densities. The combined data were subjected to analysis of variance in a completely randomized design with the SAS general linear models (GLM) procedure. Means of different treatments for the various variables were compared using Fisher's protected least significant difference test at $P=0.05$ within each soil condition and cultivar. 
Field experiment data for the 2 years were analyzed separately for variance in a completely randomized block design with the SAS GLM procedure. Single degreeof-freedom contrasts were used to evaluate the effects of $R$. solani alone and in combination with different herbicides.

\section{RESULTS AND DISCUSSION}

Greenhouse study. Main effects of cultivar and treatment and interactions of cultivar-soil, cultivar-treatment, and soilroot rot severity. Also, plant stand was significantly affected by main effects of cultivar and treatment, and by the interaction between cultivar and treatment (Table $3)$.

In autoclaved soil, root rot severity increased significantly with treatment $R$. solani + pendimethalin in BSR 101 compared with the control (no herbicide and no $R$. solani) and $R$. solani alone. In cv. $\mathrm{P}$ 93B01, root rot severity varied with treatments. All the treatments except $R$. solani + pendimethalin showed a significant increase in root rot severity compared with treatment were significant with respect to

the control. The other treatments did not differ from the $R$. solani-alone treatment in root rot severity (Table 4). Plant stand was significantly reduced in all the treatments for both cultivars relative to the control. Only treatment $R$. solani + pendimethalin produced a significant decrease in plant stand in P 93B01 compared with $R$. solani alone (Table 4 ). The variation exhibited by the two cultivars treated with pendimethalin with respect to root rot and plant stand in autoclaved soil could be due to difference in tolerance to pendimethalin or to differential susceptibility to $R$. solani root rot among the two cultivars (Table 4).

In nonautoclaved soil, root rot severity differed between the cultivars. In BSR 101, none of the treatments exhibited significant differences in root rot severity (Table 4). In $\mathrm{P}$ 93B01, $R$. solani alone and $R$. solani in combination with herbicides imazethapyr (applied at both GSs) and glyphosate (applied at GS V2) showed more root rot symptoms compared with the control. However, none of the treatments showed a significant increase in root rot severity relative to $R$. solani alone. Plant stand was

Table 4. Effect of combinations of herbicides and Rhizoctonia solani on root rot severity (RRS) and plant stand in glyphosate-sensitive (BSR 101) and glyphosate-tolerant (Pioneer 93B01) cultivars under greenhouse conditions ${ }^{y}$

\begin{tabular}{|c|c|c|c|c|}
\hline \multirow[b]{2}{*}{ Treatment } & \multicolumn{2}{|c|}{ BSR 101} & \multicolumn{2}{|c|}{ Pioneer 93B01 } \\
\hline & RRS & Plant stand & RRS & Plant stand \\
\hline \multicolumn{5}{|l|}{ Autoclaved soil } \\
\hline Control & $1.1 \mathrm{~b}$ & $5 \mathrm{a}$ & $1.4 \mathrm{c}$ & $4 \mathrm{a}$ \\
\hline R. solani & $1.4 \mathrm{~b}$ & $2 \mathrm{~b}$ & $2.9 \mathrm{ab}$ & $3 \mathrm{~b}$ \\
\hline R. solani + pendimethalin & $2.0 \mathrm{a}$ & $2 \mathrm{~b}$ & $1.9 \mathrm{c}$ & $2 \mathrm{c}$ \\
\hline R. solani + imazethapyr $^{\mathrm{z}}$ & $1.1 \mathrm{~b}$ & $2 \mathrm{~b}$ & $3.4 \mathrm{a}$ & $3 \mathrm{~b}$ \\
\hline R. solani + imazethapyr $\mathrm{r}^{\mathrm{z}}$ & $1.3 \mathrm{~b}$ & $2 \mathrm{~b}$ & $3.2 \mathrm{a}$ & $3 \mathrm{~b}$ \\
\hline R. solani + glyphosate $\mathrm{e}^{\mathrm{z}}$ & $\ldots$ & $\ldots$ & $2.5 \mathrm{~b}$ & $3 \mathrm{~b}$ \\
\hline R. solani + glyphosate ${ }^{\mathrm{z}}$ & $\ldots$ & $\ldots$ & $2.8 \mathrm{ab}$ & $3 \mathrm{~b}$ \\
\hline \multicolumn{5}{|l|}{ Nonautoclaved soil } \\
\hline Control & $1.7 \mathrm{a}$ & $4 \mathrm{a}$ & $1.5 \mathrm{c}$ & $4 \mathrm{a}$ \\
\hline R. solani & $1.8 \mathrm{a}$ & $2 \mathrm{~b}$ & $2.9 \mathrm{a}$ & $3 \mathrm{~b}$ \\
\hline R. solani + pendimethalin & $1.6 \mathrm{a}$ & $2 \mathrm{~b}$ & $2.0 \mathrm{c}$ & $1 \mathrm{c}$ \\
\hline$R$. solani + imazethapyr $^{\mathrm{z}}$ & $1.5 \mathrm{a}$ & $2 \mathrm{~b}$ & $3.4 \mathrm{a}$ & $3 \mathrm{~b}$ \\
\hline R. solani + imazethapyr $\mathrm{r}^{\mathrm{Z}}$ & $1.6 \mathrm{a}$ & $2 \mathrm{~b}$ & $2.8 \mathrm{a}$ & $3 \mathrm{~b}$ \\
\hline R. solani + glyphosate $^{\mathrm{z}}$ & $\ldots$ & $\ldots$ & $2.3 \mathrm{~b}$ & $3 \mathrm{~b}$ \\
\hline R. solani + glyphosate $^{\mathrm{z}}$ & $\ldots$ & $\ldots$ & $1.8 \mathrm{c}$ & $3 \mathrm{~b}$ \\
\hline
\end{tabular}

${ }^{y}$ RRS taken at termination of the experiment (R1 growth stage). Values followed by the same letters are not significantly different from each other for each variable within each soil condition and cultivar according to Fisher's least significant difference test at $P=0.05 ; \ldots=$ treatment not applied.

${ }^{\mathrm{z}}$ Herbicides imazethapyr and glyphosate applied at growth stages V2 and V4 respectively, after planting. significantly reduced in BSR 101 with all treatments compared with the control (no herbicide and no $R$. solani). However, when $R$. solani + herbicide treatments were compared with $R$. solani alone, they were not significantly different with respect to plant stand. Cv. P 93B01 showed a similar response in plant stand with the various treatments compared with the control with the exception of treatment $R$. solani + pendimethalin, which significantly decreased plant stand compared with the control and $R$. solani alone (Table 4).

Root rot severity and plant stands were similar with cvs. BSR 101 and P 93B01 under both soil conditions tested except with pendimethalin. The differential response of the two cultivars to pendimethalin with respect to root rot and plant stand may be due to different tolerance levels to pendimethalin or a difference in genetic tolerance to $R$. solani. The dinitroanaline class of herbicides (to which pendimethalin belongs) has been shown to affect normal cell division in plants (12).

Field study. Analysis of variance revealed a significant treatment effect on root rot severity for both years whereas cultivar and treatment showed a significant effect on plant stand only in 1999 (Table 5).

In 1998, shoot dry weight, root rot severity, and plant stand were not significantly affected by the different $R$. solani + herbicide treatments compared with the noninoculated control and $R$. solani alone in both cultivars (Table 6). The lack of differences in root rot severity and plant stand between $R$. solani alone and the noninoculated control shows that the disease pressure was not high enough to extract differential disease resistance response between the two cultivars.

In 1999, shoot dry weight was not significantly affected by the treatments tested for either cultivar (Table 7). Root rot severity differed among treatments in both cultivars. BSR 101 exhibited a significant increase in root rot severity with treatments $R$. solani + pendimethalin and $R$. solani + imazethapyr compared with $R$. solani alone. In P 9344, only treatment $R$. solani + pendimethalin revealed a significant increase in root rot severity compared with the $R$. solani treatment (Table 7). Treat-

Table 5. Analysis of variance showing the effects of cultivar (glyphosate-sensitive and glyphosate-tolerant), treatments (Rhizoctonia solani and herbicides), and their interaction on shoot dry weight (SDWT), root rot severity (RRS), and plant stand (PS) under field conditions

\begin{tabular}{|c|c|c|c|c|c|c|c|}
\hline \multirow[b]{2}{*}{ Source $^{\mathrm{z}}$} & \multirow[b]{2}{*}{ df } & \multicolumn{2}{|c|}{ SDWT } & \multicolumn{2}{|c|}{ RRS } & \multicolumn{2}{|c|}{ PS } \\
\hline & & $F$ & $P>F$ & $\boldsymbol{F}$ & $P>F$ & $\boldsymbol{F}$ & $P>F$ \\
\hline \multicolumn{8}{|l|}{1998} \\
\hline Cultivar (C) & 1 & 0.4 & 0.55 & 0.7 & 0.41 & 0.4 & 0.52 \\
\hline Treatment $(\mathrm{T})$ & 6 & 0.8 & 0.56 & 3.3 & 0.02 & 1.3 & 0.30 \\
\hline $\mathrm{C}-\mathrm{T}$ & 6 & 0.5 & 0.74 & 2.1 & 0.11 & 0.4 & 0.81 \\
\hline \multicolumn{8}{|l|}{1999} \\
\hline Cultivar (C) & 1 & 0.3 & 0.58 & 0.7 & 0.42 & 4.1 & 0.05 \\
\hline Treatment $(\mathrm{T})$ & 16 & 1.4 & 0.17 & 2.5 & 0.007 & 7.0 & 0.0001 \\
\hline $\mathrm{C}-\mathrm{T}$ & 16 & 1.0 & 0.47 & 0.5 & 0.90 & 0.9 & 0.52 \\
\hline
\end{tabular}

${ }^{\mathrm{z}}$ Source of variation; data are from three replications for each year, with 7 treatments in 1998 and 17 treatments in 1999. 
ments affected plant stands differently between cultivars BSR 101 and P 9344 (Table 7). In BSR 101, treatments $R$. solani alone and $R$. solani + pendimethalin + imazethapyr resulted in significant decreases in plant stand relative to the noninoculated control and the $R$. solani + pendimethalin treatment, respectively. However with cultivar P 9344, only $R$. solani alone showed a significant decrease in plant stand compared with the noninoculated control and killed inoculum treatment (Table 7).

In the presence of $R$. solani, with or without herbicides, plant stands were reduced in both cultivars but the magnitude and significance in plant stand reduction varied with respect to the treatments. Compared with 1998, 1999 was a wetter year, especially early in the season, which might account in part for the decrease in plant stand with most treatments and especially with BSR 101. In addition, delayed planting in 1998 might have avoided the favorable early season environment for damping-off and root rots caused by $R$. solani. Further, the decreased plant stand in BSR 101 could be due to relative susceptibility to damping-off caused by $R$. solani compared with P 9344.

For most herbicide treatments in our field study, results are consistent with the findings by Bauske and Kirby (2), who reported no significant increase in root rot in soybean due to interactions between herbicides and $R$. solani. Our findings on the effects of pendimethalin on root rot severity agree with the results of Wiley and
Ross (20), who found increased root rot in soybean treated with trifluralin, which belongs to the same class of dinitroaniline herbicides as pendimethalin. However, our results from the greenhouse experiments with two inoculum levels showed no significant difference, which is different from Wiley and Ross's (20) observation of a significant increase in root rot with trifluralin under higher inoculum density.

Herbicide-induced stresses in conjunction with physical factors have been shown to increase predisposition of crops to plant diseases and fungal colonization $(1,2)$. Thus, the use of herbicide-tolerant cultivars could reduce herbicide-related stresses and decrease diseases compared with conventional cultivars, which lack herbicide tolerance. Although two different gly-

Table 6. Single degree-of-freedom contrasts for the effects of treatments (herbicides and Rhizoctonia solani) on shoot dry weight (SDWT), root rot severity (RRS), and plant stand (PS) in soybean cultivars BSR 101 (glyphosate-sensitive) and Pioneer 9344 (glyphosate-tolerant) under field condition in 1998y

\begin{tabular}{|c|c|c|c|c|c|c|}
\hline \multirow[b]{2}{*}{ Treatment $^{\mathrm{z}}$} & \multicolumn{2}{|c|}{ SDWT (g) } & \multicolumn{2}{|c|}{ RRS } & \multicolumn{2}{|c|}{ PS (no./m) } \\
\hline & Means & Significance & Means & Significance & Means & Significance \\
\hline \multicolumn{7}{|l|}{ BSR 101} \\
\hline CON vs RS & 11.5 vs 9.3 & $\mathrm{~ns}$ & 2.2 vs 2.5 & $\mathrm{~ns}$ & 25.0 vs 26.0 & ns \\
\hline RS vs RS+P & 9.3 vs 9.7 & ns & 2.5 vs 2.2 & ns & 26.0 vs 19.0 & ns \\
\hline RS vs RS+I & 9.3 vs 11.3 & ns & 2.5 vs 2.7 & ns & 26.0 vs 21.0 & $\mathrm{~ns}$ \\
\hline RS vs RS+G & NA & NA & NA & NA & NA & NA \\
\hline RS+P vs RS+P+I & 9.7 vs 9.3 & $\mathrm{~ns}$ & 2.2 vs 2.8 & $\mathrm{~ns}$ & 19.0 vs 20.0 & $\mathrm{~ns}$ \\
\hline $\mathrm{RS}+\mathrm{P}$ vs $\mathrm{RS}+\mathrm{P}+\mathrm{G}$ & NA & NA & NA & NA & NA & NA \\
\hline \multicolumn{7}{|l|}{ PIONEER 9344} \\
\hline CON vs RS & 9.3 vs 10.9 & $\mathrm{~ns}$ & 1.7 vs 2.2 & ns & 25.0 vs 22.0 & ns \\
\hline RS vs RS+P & 10.9 vs 9.6 & ns & 2.2 vs 2.7 & ns & 22.0 vs 14.0 & $\mathrm{~ns}$ \\
\hline RS vs RS+I & 10.9 vs 15.5 & ns & 2.2 vs 2.0 & ns & 22.0 vs 24.0 & ns \\
\hline RS vs RS+G & 10.9 vs 13.1 & ns & 2.2 vs 2.7 & ns & 22.0 vs 22.0 & ns \\
\hline RS+P vs RS+P+I & 9.6 vs 9.4 & $\mathrm{~ns}$ & 2.7 vs 2.8 & ns & 14.0 vs 19.0 & ns \\
\hline $\mathrm{RS}+\mathrm{P}$ vs $\mathrm{RS}+\mathrm{P}+\mathrm{G}$ & 9.6 vs 9.5 & ns & 2.7 vs 2.5 & $\mathrm{~ns}$ & 14.0 vs 20.0 & $\mathrm{~ns}$ \\
\hline
\end{tabular}

y Abbreviations: $\mathrm{ns}=$ not significant at $P=0.05$ within each cultivar for each variable; NA $=$ treatment not applied.

${ }^{\mathrm{z}} \mathrm{CON}=$ control, $\mathrm{RS}=$ Rhizoctonia solani, $\mathrm{P}=$ pendimethalin, $\mathrm{I}=$ imazethapyr, and $\mathrm{G}=$ glyhposate.

Table 7. Single degree-of-freedom contrasts for the effects of treatments (herbicides and Rhizoctonia solani) on shoot dry weight (SDWT), root rot severity (RRS), and plant stand (PS) in soybean cultivars BSR 101 (glyphosate-sensitive) and Pioneer 9344 (glyphosate-tolerant) under field condition in 1999y

\begin{tabular}{|c|c|c|c|c|c|c|}
\hline \multirow[b]{2}{*}{ Treatment $^{\mathrm{z}}$} & \multicolumn{2}{|c|}{ SDWT (g) } & \multicolumn{2}{|c|}{ RRS } & \multicolumn{2}{|c|}{ PS (no./m) } \\
\hline & Means & Significance & Means & Significance & Means & Significance \\
\hline \multicolumn{7}{|l|}{ BSR 101} \\
\hline CON vs KI & 5.1 vs 4.2 & $\mathrm{~ns}$ & 1.1 vs 1.2 & $\mathrm{~ns}$ & 27 vs 32 & ns \\
\hline $\mathrm{CON}$ vs RS & 5.1 vs 5.0 & $\mathrm{~ns}$ & 1.1 vs 1.3 & $\mathrm{~ns}$ & 27 vs 12 & $* *$ \\
\hline KI vs RS & 4.2 vs 5.0 & ns & 1.2 vs 1.3 & ns & 32 vs 12 & $* * *$ \\
\hline RS vs RS+P & 5.0 vs 3.7 & $\mathrm{~ns}$ & 1.3 vs 1.5 & $* *$ & 12 vs 17 & ns \\
\hline RS vs RS+I & 5.0 vs 3.2 & ns & 1.3 vs 1.5 & $* *$ & 12 vs 14 & $\mathrm{~ns}$ \\
\hline RS vs $R S+G$ & NA & NA & NA & NA & NA & NA \\
\hline RS vs RS+L & 5.0 vs 5.8 & ns & 1.3 vs 1.2 & $\mathrm{~ns}$ & 12 vs 19 & ns \\
\hline $\mathrm{RS}+\mathrm{P}$ vs RS+P+I & 3.7 vs 4.2 & $\mathrm{~ns}$ & 1.5 vs 1.5 & $\mathrm{~ns}$ & 17 vs 9 & $* *$ \\
\hline $\mathrm{RS}+\mathrm{P}$ vs $\mathrm{RS}+\mathrm{P}+\mathrm{G}$ & NA & NA & NA & NA & NA & NA \\
\hline $\mathrm{RS}+\mathrm{P}$ vs $\mathrm{RS}+\mathrm{P}+\mathrm{L}$ & 3.7 vs 3.1 & $\mathrm{~ns}$ & 1.5 vs 1.5 & $\mathrm{~ns}$ & 17 vs 14 & $\mathrm{~ns}$ \\
\hline \multicolumn{7}{|l|}{ PIONEER 9344} \\
\hline CON vs KI & 4.8 vs 4.5 & ns & 1.2 vs 1.2 & ns & 41 vs 37 & ns \\
\hline CON vs RS & 4.8 vs 5.0 & ns & 1.2 vs 1.2 & ns & 41 vs 10 & $* * * *$ \\
\hline KI vs RS & 4.5 vs 5.0 & ns & 1.2 vs 1.2 & ns & 37 vs 10 & ***** \\
\hline RS vs RS+P & 5.0 vs 3.8 & $\mathrm{~ns}$ & 1.2 vs 1.6 & ** & 10 vs 18 & $\mathrm{~ns}$ \\
\hline RS vs RS+I & 5.0 vs 3.8 & $\mathrm{~ns}$ & 1.2 vs 1.4 & $\mathrm{~ns}$ & 10 vs 15 & $\mathrm{~ns}$ \\
\hline RS vs $R S+G$ & 5.0 vs 4.3 & $\mathrm{~ns}$ & 1.2 vs 1.2 & $\mathrm{~ns}$ & 10 vs 13 & $\mathrm{~ns}$ \\
\hline RS vs RS+L & 5.0 vs 3.9 & $\mathrm{~ns}$ & 1.2 vs 1.4 & $\mathrm{~ns}$ & 10 vs 15 & $\mathrm{~ns}$ \\
\hline $\mathrm{RS}+\mathrm{P}$ vs $\mathrm{RS}+\mathrm{P}+\mathrm{I}$ & 3.8 vs 2.9 & ns & 1.6 vs 1.5 & ns & 18 vs 16 & ns \\
\hline $\mathrm{RS}+\mathrm{P}$ vs $\mathrm{RS}+\mathrm{P}+\mathrm{G}$ & 3.8 vs 4.2 & ns & 1.6 vs 1.3 & ns & 18 vs 16 & ns \\
\hline $\mathrm{RS}+\mathrm{P}$ vs $\mathrm{RS}+\mathrm{P}+\mathrm{L}$ & 3.8 vs 3.1 & $\mathrm{~ns}$ & 1.6 vs 1.4 & ns & 18 vs 20 & $\mathrm{~ns}$ \\
\hline
\end{tabular}

y Abbreviations: $\mathrm{ns}=$ not significant, $* *=P \leq 0.01, * * *=P \leq 0.001, * * * *=P \leq 0.0001$ within each cultivar for each variable; NA $=$ treatment not applied.

${ }^{\mathrm{z}} \mathrm{CON}=$ control, $\mathrm{KI}=$ killed inoculum, $\mathrm{RS}=$ Rhizoctonia solani, $\mathrm{P}=$ pendimethalin, $\mathrm{I}=$ imazethapyr, $\mathrm{G}=$ glyhposate, and $\mathrm{L}=$ lactofen. 
phosate-tolerant cultivars were tested, results from this study do not support such a hypothesis. Glyphosate-tolerant and glyphosate-sensitive cultivars had, for the most part, similar responses to $R$. solani when treated with glyphosate and other herbicides in relation to root rot and damping-off. Results of our field study tend to corroborate the findings from an earlier study where researchers found similar responses in both glyphosate-tolerant and glyphosate-sensitive soybean when treated with herbicides on the development of sudden death syndrome caused by Fusarium solani f. sp. glycines (16).

The findings of our study are complicated by the fact that root rot levels exhibited in field experiments were low. Results could differ under high root rot disease pressure and, thus, additional testing under these conditions may be beneficial.

There were some differential disease responses to the application of the different herbicides to both glyphosate-tolerant and glyphosate-sensitive soybean in greenhouse and field studies. However, damping-off and root rot caused by $R$. solani was similar in both glyphosate-tolerant and glyphosate-sensitive cultivars following application of most herbicide treatment.

\section{ACKNOWLEDGMENTS}

We thank S. Sanogo, S. Wegulo, and F. Workneh for critically reviewing this manuscript; and P. Lundeen for assistance during the course of this study.

\section{LITERATURE CITED}

1. Altman, J., and Rovira, A. D. 1989. Herbicide-pathogen interactions in soil-borne root diseases. Can. J. Bot. 66:1547-1555.

2. Bauske, E. M., and Kirby, H. W. 1992. Effects of dinitroaniline herbicides, carboxinpentachloronitrobenzene seed treatment, and Rhizoctonia disease on soybean. Plant Dis. 76:236-239.

3. Canaday, C. H., Helsel, D. G., and Wyllie, T. D. 1986. Effects of herbicide-induced stress on root colonization of soybeans by Macrophomina phaseolina. Plant Dis. 70:863-866.

4. Doupnik, B., Jr. 1993. Soybean production and disease loss estimates for the north central United States from 1989-1991. Plant Dis. 77:1170-1171.

5. Duke, S. O., ed. 1996. Herbicide-Resistant Crops: Agricultural, Environmental, Economic, Regulatory, and Technical Aspects. Lewis Publishers, Boca Raton, FL.

6. Fehr, W. R., Caviness, C. E., Burmond, D. T., and Pennington, J. S. 1971. Stage of development descriptions for soybean, Glycine max (L.) Merrill. Crop Sci. 11:929-931.

7. Holzman, B. 1999. Report leads to debate on the benefits of transgenic corn and soybean crops. Genet. Eng. News Vol 19 (8):1, 12, and 29.

8. Latunde-Dada, A. O., and Lucas, J. A. 1985. Involvement of phytoalexin medicarpin in the differential response to callus lines of lucerne (Medicago sativa) to infection by Verticillium albo-atrum. Physiol. Plant Pathol. 26:31-42.

9. Levesque, C. A., and Rahe, J. E. 1992. Herbicide interactions with fungal root pathogens, with special reference to glyphosate. Annu. Rev. Phytopathol. 30:579-602.

10. Levesque, C. A., Rahe, J. E., and Eaves, D. M. 1987. Effects of glyphosate on Fusarium spp.: its influence on root colonization of weeds, propagule density in the soil, and crop emergence. Can. J. Microbiol. 33:354-360.

11. Moesta, P., and Griesbach, H. 1982. L-aaminooxy-b-phenylpropionic acid inhibits phytoalexin accumulation in soybean with concomitant loss of resistance against Phytophthora megasperma f. sp. glycinea.
Physiol. Plant Pathol. 21:65-70

12. Morejohn, L. C., Bureau, T. E., Mole-Bajer, J., Bajer, A. S., and Fosker, D. E. 1987 Oryzalin, a dinitroanaline herbicide binds to plant tubulin and inhibits microtubule polymerization in vitro. Planta 172:252-264.

13. Nelson, B., Helms, T., Christianson, T., and Kural, I. 1996. Characterization and pathogenicity of Rhizoctonia solani from soybean. Plant Dis. 80:74-80.

14. Padgette, S. R., Kolacz, K. H., Delannay, X., Re, D. B., LaVallee, B. J., Tinius, C. N., Rhodes, W. K., Otero, Y. I., Bary, G. F., Eichholtz, D. A., Peschke, V. M., Nida, D. L., Taylor, N B., and Kishore, G. M. 1995. Development, identification, and characterization of a glyphosate-tolerant soybean line. Crop Sci. 35:1451-1461.

15. Powles, S. B., Lorraine-Colwill, D. F., Dellow, J. J., and Preston, C. 1998. Evolved resistance to glyphosate in rigid ryegrass ( $\mathrm{Lo}$ lium rigidum) in Australia. Weed Sci. 46:604607.

16. Sanogo, S., Yang, X. B., and Scherm, H. 2000. Effects of herbicides on Fusarium solani f. sp. glycines and development of sudden death syndrome in glyphosate-tolerant soybean. Phytopathology 90:57-66.

17. Sharon, A., Amsellem, Z., and Gressel, J. 1992. Glyphosate suppression of induced defense responses: increased susceptibility of Cassia obtusifolia to a mycoherbicide. Plant Physiol. 98:654-659.

18. Sinclair, J. B., and Backman, P. A. eds. 1989. Compendium of Soybean Diseases. 3rd ed. American Phytopathological Society Press, St. Paul, MN

19. Smiley, R. W., Ogg, A. G., Jr., and Cook, R. J. 1991. Influence of glyphosate on Rhizoctonia root rot, growth, and yield of barley. Plant Dis. 76:937-942.

20. Wiley, G. L., and Ross, M. A. 1974. Effect of herbicides on Rhizoctonia root rot of soybeans. (Abstr.) Proc. North Cent. Weed Control Conf. 29:33-34. 